POLSKA AKADEMIA NAUK INSTYTUT ZOOLOGII

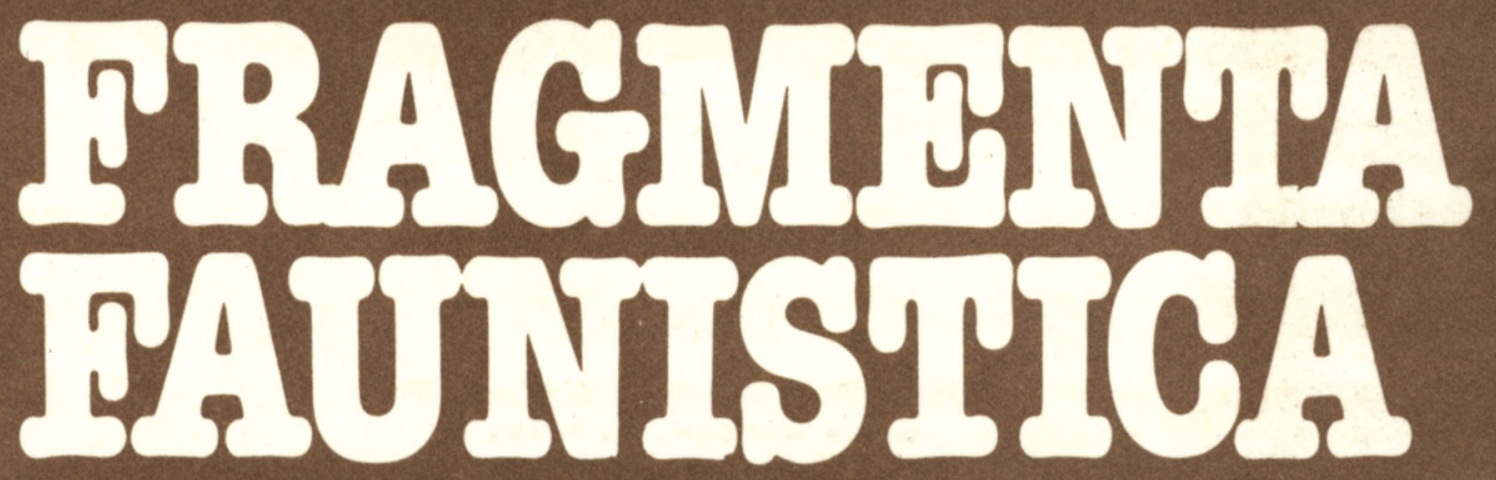

Freshwater Gastrotricha of Poland

TOM 30 NR 9-16

h.

PAŃSTWOWE WYDAWNICTWO NAUKOWE WARSZAWA - WROCŁAW 
Elżbieta Chudzicka, Henryk Garbarczyk, Andrzej Leśniak, Anna Liana, Eligiusz Nowakowski, Regina Pisarska (redaktor naczelny), Wojeiech Staręga, Barbara Zielińska (sekretarz)

\author{
Adres Redakcji \\ Instytut Zoologii Polskiej Akademii Nauk \\ 00-679 Warszawa, ul. Wileza 64 \\ (C) Copyright by Państwowe Wydawnictwo Naukowe \\ Warszawa 1986
}

ISBN 83-01-07179-6

ISSN 0015-9301

Państwowe Wydawnictwo Naukowe - Oddział we Wrocławiu

Nakład 570+80 egz. Ark. wyd. 13, ark. druk. 10. Papier druk. sat. kl. III, 80g.

Nr. zam. 1085/86. J-9. Cena 260 zł

Wrocławska Drukarnia Naukowa 


\section{Freshwater Gastrotricha of Poland}


Prace wykonane w ramach Problemu Międzyresortowego MR II-3. 


\section{TREŚĆ - CONTENTS}

$\mathrm{Nr}$ 9. J. Kisielewski. Taxonomic notes on freshwater gastrotrichs of the genus Aspidiophorus VoIgt (Gastrotricha: Chaetonotidae), with descriptions of four new species . . . . . . . . . . . . . . . . . . .

Nr 10. J. Kisielewski, G. Kisielewska. Freshwater Gastrotricha of Poland. I. Gas. trotricha from the Tatra and Karkonosze Mountains . . . . . . . . . . .

Nr 11. G. Kisielewska, J. Kisielewski. Freshwater Gastrotricha of Poland. II. Gas-
trotricha from the seaside lakes in the Słowiński National Park . . . . .

Nr 11. G. Kisielewska, J. Kisielewski. Freshwater Gastrotricha of Poland. II. Gas-
trotricha from the seaside lakes in the Słowiński National Park . . . . .

Nr 12. G. Kisielewska, J. Kisielewski. Freshwater Gastrotricha of Poland. III. Gustrotricha from the Białowieża Forest and the Białowieża Glade . . . . .

$\mathrm{Nr}$ 13. T. Nesteruk. Freshwater Gastrotricha of Poland. IV. Gastrotricha from fish ponds in the vicinity of Siedlce . . . . . . . . . . . . . .

Nr 14. G. Kisielewska, J. Kisielewski. Freshwater Gastrotricha of Poland. V. Gas. trotricha of alder woods . . . . . . . . . . . . . . .

Nr 15. A. Szkutnik. Freshwater Gastrotricha of Poland. VI. Gastrotricha of small astatic water bodies with rush vegetation .............

Nr 16. J. Kisielewski. Freshwater Gastrotricha of Poland. VII. Gastrotricha of extremely eutrophicated water bodies ............ 267 
Cena 260 zl 